\title{
Exogenous ochronosis: case report and literature review
}

\author{
Ocronose exógena: relato de caso e revisão de literatura
}

\author{
Viviane Maria Rocha Martins ${ }^{1}$ \\ Natália de Carvalho Portela ${ }^{3}$ \\ Lucidi Maria Saraiva Gonçalves ${ }^{4}$
}

\author{
Antônio Renê Diógenes de Sousa² \\ Celina Aguiar Frota Tigre ${ }^{1}$ \\ Rômulo José de Lucena Castro Filho ${ }^{3}$
}

\begin{abstract}
Exogenous ochronosis is a rare, cosmetically disfiguring condition, resulting from the longterm use of topical hydroquinone in treatment of melasma. It manifests as gray-brown or blue-black macules in hydroquinone-exposed regions. The exact incidence of ochronosis is unknown. High rates have been reported in the South African population, and it is rare in the United States. We report the case of a patient who developed exogenous ochronosis while using topical hydroquinone. It is necessary to recognize this disorder at the earliest stage and discontinue hydroquinone immediately, as its treatment is difficult. Sun exposure facilitates the formation of exogenous ochronosis and must be strictly avoided, although it is a practical problem in the tropical climate of Brazil, particularly for those who work outdoors.
\end{abstract}

Keywords: Hydroquinones; Melanosis; Ochronosis

Resumo: Ocronose exógena é uma condição rara, cosmeticamente desfigurante, devido ao uso tópico indiscriminado de hidroquinona para tratamento do melasma. Manifesta-se como máculas marrom-acinzentadas ou preto-azuladas em áreas cutâneas do uso de hidroquinona. A exata incidência de ocronose Exógena é desconhecida. Altos índices têm sido relatados em populações sul-africanas, sendo rara nos Estados Unidos. Relatamos um caso de uma paciente que desenvolveu ocronose Exógena durante uso de hidroquinona para tratamento do melasma. É necessário o reconhecimento dessa patologia no seu estágio precoce e imediata descontinuação da droga, pois seu tratamento é difícil. A exposição solar é um fator precipitante e deve ser estritamente evitada, embora isso seja difícil no clima tropical do Brasil, especialmente para aqueles que trabalham ao ar livre.

Palavras-chave: Hidroquinonas; Melanose; Ocronose

Received on 11.11.2010.

Approved by the Advisory Board and accepted for publication on 30.08.2011.

* Study carried out at the Dermatology Center Dona Libânia (Centro de Dermatologia Dona Libânia) - Fortaleza (CE), Brazil.

Conflict of interest: None

Financial funding: None

Resident of Dermatology, Dermatology Center Dona Libânia (Centro de Dermatologia Dona Libânia) - Fortaleza (CE), Brazil.

Professor of Dermatology, State University of Ceará (Universidade Estadual do Ceará - UECE) and of Edson Queiroz Foundation - University of Fortaleza (Fundação Edson Queiroz - Universidade de Fortaleza - UNIFOR). Coordinator of the residency program in Dermatology, Dermatology Center Dona Libânia (Centro de Dermatologia Dona Libânia) - Fortaleza (CE), Brazil.

Medical student of the State University of Ceará (Universidade Estadual do Ceará (UECE) - Fortaleza (CE), Brazil.

Physician, Dermatologist of the Dermatology Center Dona Libânia (Centro de Dermatologia Dona Libânia) - Fortaleza (CE), Brazil.

(C)2012 by Anais Brasileiros de Dermatologia 


\section{INTRODUCTION}

Exogenous ochronosis (EO) is a rare disease, although well known for the adverse effects caused by topical therapy with hydroquinone (HQ). ${ }^{1}$ In this pathology, a microscopic deposition of ocher-colored pigment is found in the dermis, as a result of prolonged use of this medication. ${ }^{1,2}$ It is a condition clinically and histopathologically similar to endogenous ochronosis, also known as alkaptonuria; the difference between them is that it does not present systemic manifestations such as history of dark urine, gray-blue or gray-brown coloration of cartilages, conjunctive and arthropathy, while in EO the affected area is limited to that treated with $\mathrm{HQ}{ }^{3}$

In 1975, Findlay described the first EO case related to HQ, and in 1912 Berddard and Plumtre described an EO case in a patient that had used phenol to treat a lower limb ulcer. ${ }^{4}$

Frequently used for the treatment of melasma, hydroquinone interferes in skin pigmentation through alteration of melanin formation, in interaction with copper at the site of tyrosinase activity and in inhibition of DNA and RNA synthesis. ${ }^{3}$

We report a case of exogenous ochronosis in patient classified at stage II of Dogliotte, following use of hydroquinone in the treatment of melasma.

\section{CASE REPORT}

A 64-year-old female patient, Fitzpatrick's System phototype IV, domestic worker, mentioned progressive onset of dark facial lesions three years past, following use of hydroquinone $4 \%$ in hydroalcoholic solution for two years for treatment of asthma. She denied any other symptom, similar family history, alteration in urine color, hyperpigmentation of the sclera, axillae or over articulations, use of oral medication and comorbidities.

At the dermatological examination she presented blue-black macules and papules on the face, some of them confluent, predominantly on the bilateral malar region, forehead, chin and dorsum of nose (Figures 1 and 2). She also presented photoaging, with marked folds and expression lines.

The histopathological examination is demonstrated in figures 3 and 4 . The presence of comma or banana-shaped ochronotic collagen bundles is a characteristic of ochronosis, both endogenous and exogenous; is is not possible to distinguish, merely through histopathology, between the two forms.

\section{DISCUSSION}

The association between EO and the topical use of hydroquinone has been well established in the literature. ${ }^{1}$ The exact incidence of the disease is unknown. ${ }^{2}$ High rates have been reported in the South African population, with lower rates among Hispanics and Caucasians and rare cases in the USA. ${ }^{1}$ Described in 28 to $35 \%$ of the Black population, several factors have been pointed out as causative of this high incidence, among them the elevated concentrations of hydroquinone in South African skin bleaching creams before 1984, presence of agents that cause irrevers8ible depigmentation in these products, such as t-butyl alcohol up to 1986, mercury compounds and antiacne products containing resorcinol.

Clinically it presents as brown-gray or blueblack pigmentation, asymptomatic, in photoexposed

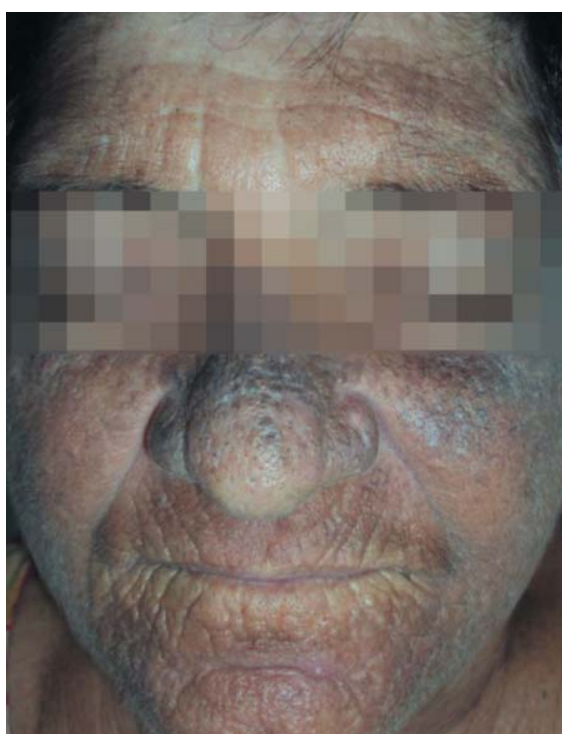

Figure 1: Blueblack macules and papules on bilateral malar region, forehead, chin and dorsum of nose

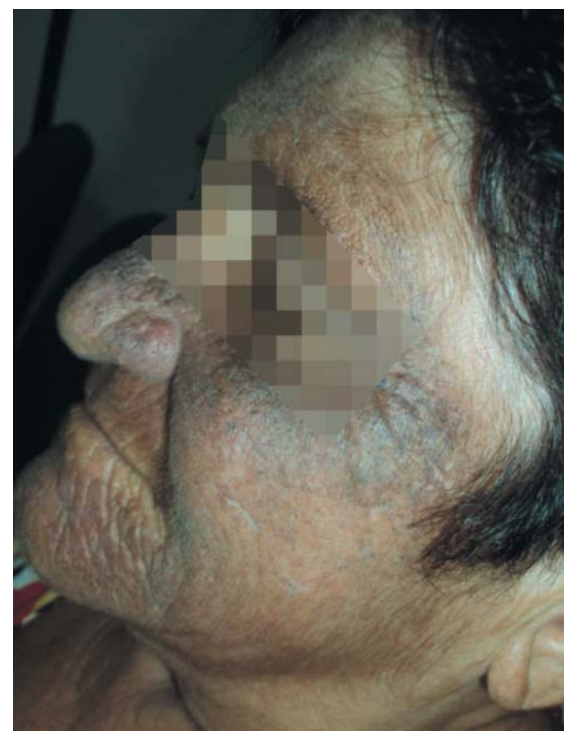

Figure 2: Blueblack macules and papules on the face 


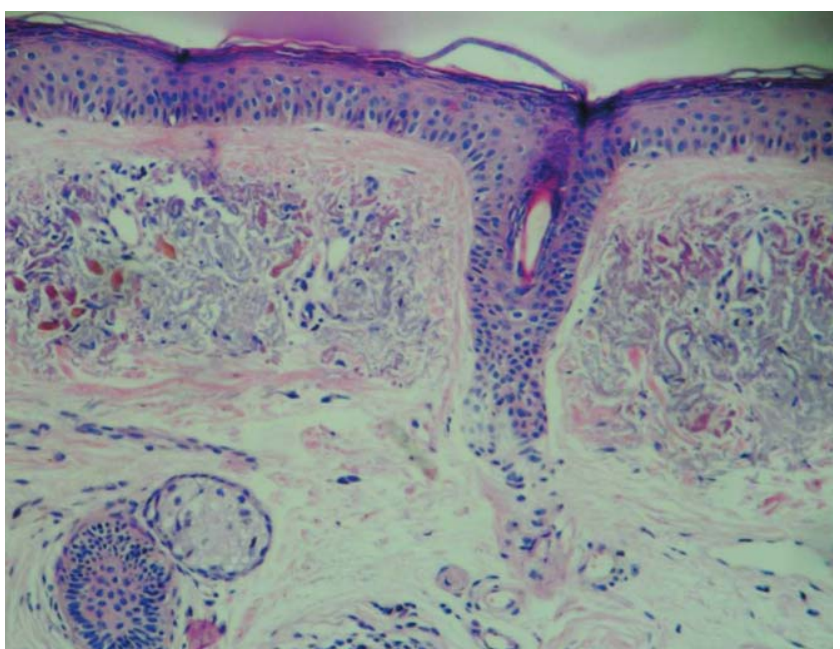

FigURE 3: Normal corneal layer, atrophic epidermis; the presence of intense actinic elastosis and ocher-colored fibers is noticed in the dermis

areas or on contact sites, mainly the face, neck, back and extremity extensor surface. ${ }^{4,5}$ In 1979, the SouthAfrican author Dogliotte classified EO into three clinical stages: Stage I - erythema and mild hyperpigmentation; Stage II - pigmented colloid milium ("caviarlike lesions") and some atrophy; and Stage III - papulo-nodular lesions, with or without inflammation. ${ }^{4,5,6}$

The predisposing factors include Fitzpatrick's System high phototype, lack of sun protection, skin irritation and vigorous friction, and HQ use at concentrations higher than $3 \%$ for a period longer that six months, although there have been reports of EO cases with the use of $2 \%$ concentrations and for less than six months. ${ }^{3,4}$

Several theories were formulated in an attempt to describ the exact pathogenesis of EO. ${ }^{1,4}$ The most accepted theory is Penneys', which proposes that HQ inhibits the local activity of the homogentisic acid oxidase enzyme, resulting in accumulation of homogentisic acid, that is polymerized, forming the ochronotic pigment and being deposited in the dermis. ${ }^{1,47}$ EO may also occur as a result of contact with other chemical products, such as resorcin, phenol, mercury, picric acid and systemic antimalarials, by means of mechanisms also unknown. ${ }^{1,2,3}$

The EO diagnosis is histologically confirmed by the existence of pigmentary incontinence, solar elastosis, presence of banana-shaped yellow-brown (ocher) fibers in the papillary dermis and eventual collagen degeneration. ${ }^{1,4,5}$ Occasionally, colloid milium and granulomas may be detected. ${ }^{3,5}$ It should be pointed out that, for the EO diagnosis, the possibility of alkaptonuria should be excluded, at least from a clinical point of view. ${ }^{4}$

EO treatment is not easy, therefore prevention

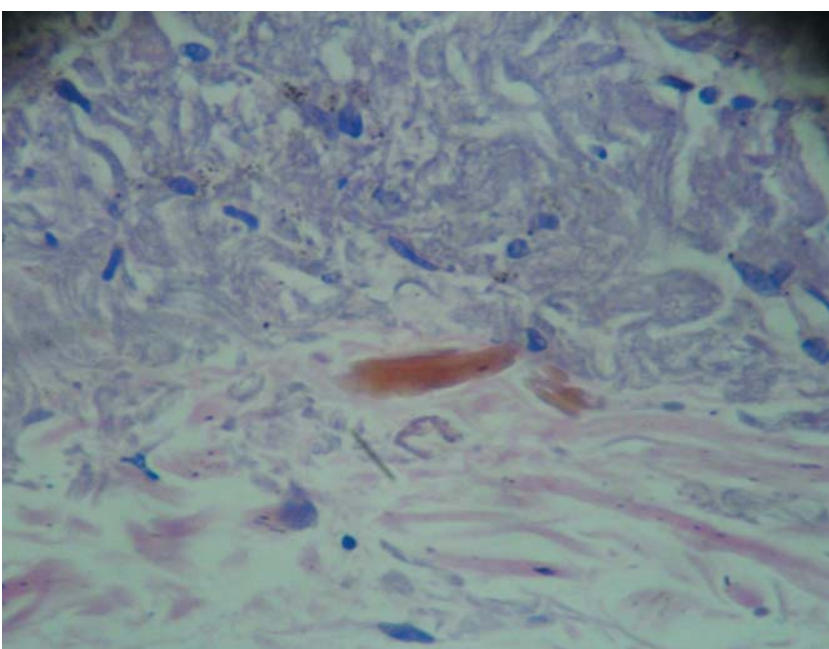

FigURE 4: Golden to brownish-colored fragmented collagen fibers, containing ochronotic pigment

is extremely important. The use of lower HQ concentrations, sun protection, early diagnosis of irritation and suspension of treatment in case there is no clinical improvement within six months are measures that should be adopted for EO prevention. ${ }^{1}$ Avoiding the causative agent of the disease is the first step to be taken and has been proven to be beneficial, although the results are seen only a few years after interruption of the treatment. ${ }^{8}$

Treatments with trichloroacetic acid and cryotherapy were shown to be inefficient. It was demonstrated that, in some cases, the retinoic acid improves the lesions, while in others it causes transient hyperpigmentation. ${ }^{8}$ Low potency corticosteroids associated with photoprotection have had good results in EO treatment. ${ }^{8}$ Satisfactory results were also described with dermoabrasion, $\mathrm{CO}_{2}$ laser, glycolic acid peelings and Q-switched laser. ${ }^{1,4,8}$ However, the results are not uniform and this condition continues to be of difficult treatment.

Our patient has a phototype that corresponds to the most frequently affected by EO. ${ }^{1,4}$ The concentration of hydroquinone used and the time of exposure to the drug were above the minimum values established for development of the disease. ${ }^{1}$ The use of hydroquinone in hydroalcoholic solution, which has a significantly higher penetration in the skin was also an important contributing factor for EO development in this case.

The clinical presentation and histopathological characteristics of the lesions are a classical presentation of EO, consonant with descriptions in the literature. Based on them, the patient may be classified in stage II of Dogliotte, "caviar-like lesions". 3,4,5,6

The patient did not mention use of any other 
drug related with EO development and did not present signs or symptoms of endogenous ochronosis, being thus excluded the possibility of alkaptonuria.

$\mathrm{EO}$ is a rare condition, cosmetically disfiguring and psychologically debilitating, that deserves early diagnosis and interruption of the causative drug in adequate time. A late or erroneous diagnosis may lead the patient to continuous drug application, oftenti- mes in greater quantity on the affected areas, in an attempt to clear the "new spots", resulting in worsening hyperpigmentation. ${ }^{8}$

HQ prescription to any patient should be accompanied by orientation about the possible side effects, including the information that the drug should be used for a limited period and always with medical follow-up., ${ }^{4,9}$

\section{REFERENCES}

1. Zawar VP, Mhaskar ST. Exogenous ochronosis following hydroquinone for melasma. J Cosmet Dermatol. 2004;3:234-6.

2. Tan SK, Sim CS, Goh CL. Hydroquinone-induced exogenous ochronosis in Chinese - two case reports and a review. Int J Dermatol. 2008;47:639-40.

3. Bongiorno MR, Aricò M. Exogenous ochronosis and striae atrophicae following the use of bleaching creams. Int J Dermatol. 2005;44:112-5.

4. Charlín R, Barcaui CB, Kac BK, Soares DB, Rabello-Fonseca R, Azulay-Abulafia L. Hydroquinone-induced exogenous ochronosis: a report of four cases and usefulness of dermoscopy. Int J Dermatol. 2008; 47:19-23.

5. Bellew SG, Alster TS. Treatment of exogenous ochronosis with a Q-Switched alexandrite (755 nm) laser. Dermatol Surg. 2004;30:555-8.

6. Dogliotte M, Leibowitz M. Granulomatous ochronosis - a cosmetic-induced skin disorder in blacks. S Afr Med J. 1979;56:757-60.

7. Penneys NS. Ochronosis-like pigmentation from bleaching creams. Arch Dermatol. 1985;121:1239-40.
8. Levin CY, Maibach H. Exogenous ochronosis. An update on clinical features, causative agents and treatment options. Am J Clin Dermatol. 2001;2:213-7.

9. Ribas J, Schettini APM, Cavalcante MSM. Ocronose exógena induzida por hidroquinona: relato de quatro casos. An Bras Dermatol. 2010;85:699-703.

\author{
MAILING ADDRESS: \\ Viviane Maria Rocha Martins \\ Rua Pedro I, 1033 - Centro \\ 60035-101 Fortaleza, CE \\ E-mail: vivianemartins@botmail.com
}

How to cite this article: Martins VMR, Sousa ARD, Portela NC, Tigre CAF, Gonçalves LMS, Castro Filho RJL. Exogenous ochronosis: case report and literature review. An Bras Dermatol. 2012;87(4):633-6. 